\title{
Google Translate in Tarjamah Learning at Arabic Language Education UIN Walisongo Semarang
}

\author{
Mustolikh Khabibul Umam \\ UIN Sunan Kalijaga Yogyakarta \\ mustolikh99@gmail.com
}

\author{
Received: 30-12-2020
}

Revised: 11-01-2021

Accepted: 31-01-2021

\begin{abstract}
The development of translator applications in the last decade, has had a significant impact on the results of learning tarjamah to students majoring in Arabic language education (PBA), the ability of translator applications is increasing all the time with improved data retrieval processes and systematic search procedures. A number of Students of PBA UIN Walisongo Semarang consider the application of translation known as Google Translate to be an indispensable tool to save time and effort. However, how this application has a role to play in the process of learning tarjamah. This research is intended to answer the problem: 1) What is the role of Google Translate in the process of translating Arabic text?. 2) What impact does it have on the use of Google Translate apps?. This research is a qualitative research category that is analyzed using statistical techniques with data collection techniques in the form of interviews, questionnaires and also documentation. The data is analyzed using qualitative descriptive analysis strategies and qualitative verification. The results showed that Google Translate has a considerable contribution to the translation process of PBA students. The average test results of questionnaires get more than $56 \%$ in several categories, namely in terms of intensity of use, function, effectiveness, how to use, impact of use, efficiency, quality, facilities, benefits, disadvantages and advantages. The use of this machine translator also has an impact on students. The results showed $58 \%$ for positive impact and $42 \%$ for negative impact on the use of internetbased translation application.
\end{abstract}

Keywords: Arabic language, Google Translate, Translation

\begin{abstract}
Abstrak
Semakin berkembangnya aplikasi mesin penerjemah dalam satu dasawarsa terakhir, telah berdampak signifikan terhadap hasil pembelajaran tarjamah pada mahasiswa jurusan pendidikan bahasa Arab (PBA), kemampuan aplikasi mesin penerjemah semakin meningkat setiap waktunya dengan perkembangan proses pengambilan data dan prosedur sistematis pencarian. Sejumlah mahasiswa PBA UIN Walisongo Semarang menganggap aplikasi penerjemahan yang dikenal sebagai Google Translate merupakan alat yang sangat diperlukan untuk menghemat waktu dan usaha. Namun, bagaimana aplikasi ini mempunyai peranan terhadap proses pembelajaran tarjamah. Penelitian ini dimaksudkan untuk menjawab permasalahan: 1) Bagaimana peranan Google Translate dalam proses penerjemahan teks Arab?. 2) Bagaimana dampak yang ditimbulkan terhadap penggunaan aplikasi Google Translate?. Penelitian ini merupakan kategori penelitian kualitatif yang dianalisis menggunakan teknik statistik dengan teknik pengumpulan data berupa wawancara, angket dan juga dokumentasi. Data tersebut kemudian dianalisis menggunakan strategi analisis deskriptif kualitatif dan verifikasi kualitatif. Hasil penelitian menunjukan Google Translate memiliki kontribusi yang cukup besar terhadap proses penerjemahan mahasiswa PBA. Rata-rata hasil pengujian angket mendapatkan lebih dari $56 \%$ dalam beberapa kategori, yaitu dari segi intensitas penggunaan, fungsi, keefektifan, cara penggunaan, dampak penggunaan, keefisienan, kualitas, fasilitas, manfaat, kekurangan dan kelebihan. Penggunaan mesin penerjemah ini juga memiliki dampak terhadap mahasiswa. Hasil dari penelitian menunjukan angka $58 \%$ untuk dampak positif dan $42 \%$ untuk dampak negatif terhadap penggunaan aplikasi penerjemahan berbasis internet ini.
\end{abstract}

Kata Kunci: Bahasa Arab, Google Translate, Penerjemaban

(C) 2021 Mustolikh Khabibul Umam

This work is licensed under a Creative Commons Attribution-ShareAlike 4.0 International License. 


\section{Pendahuluan}

Beberapa tahun terakhir salah satu teknologi yang telah banyak membantu mahasiswa untuk mengembangkan keterampilan belajar bahasa Arab dalam menerjemahkan adalah Google Translate. Memang, jutaan orang di seluruh dunia menggunakan layanan ini untuk penerjemahan setiap hari, dan semakin banyak pelajar bahasa Arab yang menggunakannya untuk tujuan belajar bahasa. Namun, kecanggihan mesin penerjemah ini baru mulai dikaji oleh para peneliti sekitar sepuluh tahun terakhir ${ }^{1}$. Google Translate merupakan aplikasi penerjemahan berbasis online yang diciptakan oleh Google Company dengan tujuan untuk menerjemahkan teks atau pesan dari bahasa satu ke bahasa yang lain. Saat ini dapat diakses melalui web bersama dengan aplikasi / Smart Phone. Pada tahun 2019 Google Translate mendukung lebih dari 110 bahasa. Google Translate didasarkan pada terjemahan mesin statistik, yang bekerja dengan menganalisis ratusan juta pasang teks dwibahasa alami. ${ }^{2}$

Sejak pertama kali dikembangkan pada April 2006, aplikasi ini telah digunakan oleh lima ratus juta orang di seluruh dunia untuk menerjemahkan lebih dari seratus miliar kata per-hari. ${ }^{3}$ Ini dimulai sebagai aplikasi web tetapi dengan penyebaran teknologi seluler, sebuah aplikasi diproduksi dalam bentuk yang dapat diunduh untuk digunakan pada perangkat seluler apa pun. Aplikasi Google Translate menyediakan layanan terjemahan dalam berbagai bahasa, oleh sebab itu banyak mahasiswa PBA tertarik untuk menggunakan aplikasi penerjemah dalam membantu mereka menerjemahkan teks berbahasa Arab dan mengatasi setiap kendala yang mereka hadapi saat melakukan penerjemahan. Para mahasiswa biasanya menggunakan Google Translate untuk menyelesaikan tugas dari kampus, dan peran mesin penerjemah ini tidak dapat dihindari karena aplikasi ini sudah tersimpan pada smart phone mereka yang selalu siap untuk digunakan.

Google Translate paling mudah didefinisikan dalam hal fitur yang ditawarkan kepada para penggunanya. Menurut Ducar dan Schocket ${ }^{4}$, Google Translate menawarkan terjemahan instan dari kata atau frasa yang diketik, serta fasilitas yang terkait dengan tiga keterampilan lainnya: mendengarkan, berbicara, dan membaca. Google Translate memungkinkan fitur seperti menerjemahkan gambar teks ke bahasa lain, opsi lainnya yaitu percakapan dwibahasa dalam menerjemahkan sebuah ungkapan setelah pengguna mengucapkan kata atau frasa yang akan di terjemahkan.

Di Indonesia, mahasiswa PBA banyak menggunakan Google Translate sebagai alat bantu mereka, terutama mereka yang belajar di kampus. Bahasa Indonesia adalah bahasa pertama yang digunakan di Indonesia, dan bahasa Arab diajarkan sebagai bahasa kedua serta menjadi mata pelajaran wajib dalam sistem pendidikan di UIN Walisongo jurusan PBA. Bahasa Arab disebut sebagai bahasa kedua di UIN Walisongo, berdasarkan asumsi bahwa setiap bahasa tambahan ke bahasa pertama adalah bahasa kedua. ${ }^{5}$ Mayoritas mahasiswa di kampus yang mengambil jurusan bahasa Arab di UIN Walisongo merujuk ke Google Translate untuk membantu mereka dalam tugas menerjemahkan ${ }^{6}$. Oleh karena itu, para peneliti di bidang pendidikan bahasa telah disarankan

${ }^{1}$ Garcia, I \& Pena, M.I., Machine translation-assisted language learning: writing for beginners. Computer Assisted Language Learning, 24 (5),471487. Retrieved from http://dx.doi.org/10.1080/09588221.201. (2011).

${ }^{2}$ Koehn, P., Statistical Machine Translation. Cambridge: Cambridge University Press. (2009).

${ }^{3}$ Turovsky, B. Ten Years of Google Translate. Google Translate. Retrieved from https://www.blog.google/products/translate/ten-years-of-google-translate/. (2016).

${ }^{4}$ Ducar, C., \& Schocket, D. H., Machine Translation and the L2 Classroom: Pedagogical Solutions for Making Peace with Google Translate. Foreign Language Annals,51(4), 779-795. https://doi.org/10.1111/flan.12366. (2018).

${ }_{5}^{5}$ Dewaele, J.-M, Why the Dichotomy 'L1 Versus LX User' is Better than 'Native Versus Non-native Speaker'. Applied Linguistics, 39(2), 236-240. https://doi.org/10.1093/applin/amw055. (2018).

${ }^{6}$ Alhaisoni, E., \& Alhaysony, M, An Investigation of Saudi EFL University Students' Attitudes towards the Use of Google Translate. International Journal of English Language Education, 5 (1), 72-82. https://doi.org/10.5296/ijele.v5i1.10696. (2017). 
untuk menyelidiki Google Translate dan kontribusi apa pun yang diberikan penggunaannya terhadap proses pembelajaran bahasa Arab. ${ }^{7}$ Penelitian ini menjawab panggilan ini dengan mengeksplorasi kemampuan Google Translate yang dirasakan oleh Mahasiswa PBA di UIN Walisongo Semarang. Ini juga bertujuan untuk mengungkap seberapa jauh penjelejahan mereka dengan Google Translate

Sebuah studi tentang mesin penerjemah yang dikaji Garcia, ${ }^{8}$ menemukan bahwa pelajar dapat memperoleh manfaat dari menggunakan mesin penerjemah lebih dari pelajar yang menggunakan kamus tradisional. Menariknya, mereka menemukan bahwa menggunakan terjemahan mesin juga membantu pelajar pemula untuk berkomunikasi dengan lebih baik di antara mereka sendiri. Josefsson ${ }^{9}$ mempelajari strategi dan sikap beberapa siswa terhadap proses penerjemahan pembelajaran bahasa. Dia menyimpulkan bahwa sebagai alat pendukung pada ponsel siswa, Google Translate memiliki kinerje lebih baik daripada kamus tradisional dengan kecepatan dan akurasi yang lebih tinggi terutama untuk terjemahan frasa dan kata-kata teknis. Namun demikian, dia menemukan bahwa Google Translate terbukti kurang berguna untuk memberikan solusi tata bahasa.

Penelitian lain oleh $\mathrm{Jin}^{10}$ menunjukkan bahwa sebagai kamus online, Google Translate adalah alat online kedua yang paling banyak digunakan oleh pelajar bahasa karena kenyamanannya. Namun, mereka menyimpulkan bahwa pelajar umumnya menggunakan Google Translate hanya sebagai alat tambahan karena kurangnya penjelasan tata bahasa. Temuan penelitian mereka mengkonfirmasi bahwa pelajar percaya penggunaan alat online, seperti Google Translate dalam mempercepat keterampilan membaca dan menulis bahasa asing sambil mengurangi kecemasan belajar mereka. Namun, para peneliti mengingatkan agar lebih berhatihati karena kamus online gagal memberikan penjelasan yang jelas kepada siswa dan umumnya mengabaikan konteks.

Baru-baru ini Groves ${ }^{11}$ menekankan implikasi penggunaan teknologi penerjemahan mesin seperti Google Translate untuk melakukan tugas dalam pembelajaran bahasa kedua. Dalam studi sampel mereka meminta para peserta untuk menulis esai dalam bahasa asli mereka sendiri dan kemudian esai ini diterjemahkan menggunakan Google Translate, hasilnya menunjukkan bahwa versi terjemahan mesin memiliki kesalahan dan kelemahan yang tidak sesuai dengan harapan lembaga akademik. Bahkan, Groves percaya bahwa Google Translate dapat memiliki pengaruh besar pada pengajaran bahasa untuk tujuan akademik pada siswa dan guru. Oleh karena itu instruktur di bidang pengajaran bahasa perlu bekerja keras dalam menghadapi mesin penerjemah tanpa menghilangkannya secara total.

Secara keseluruhan penelitian ini bertujuan untuk menyelidiki penggunaan Google Translate sebagai alat tambahan dalam membantu mahasiswa PBA UIN Walisongo Semarang khususnya dalam proses penerjemahan teks Arab serta bagaimana dampak yang ditimbulkan terhadap penggunaan aplikasi Google Translate tersebut. Hasil contoh penerjemahan yang mereka

${ }^{7}$ Amin, E. A.-R, A Review of Research into Google Apps in the Process of English Language Learning and Teaching. Arab World English Journal,11(1), 399-418. https://doi.org/10.24093/awej/vol11no1.27. (2020).

${ }^{8}$ Garcia, I., \& Pena, M. I, Machine translation-assisted language learning: writing for beginners. Computer Assisted Language Learning, 24 (5), 471-487. Retrieved from http://dx.doi.org/10.1080/09588221.2011.582687. (2011).

${ }^{9}$ Josefsson, E, Contemporary Approaches to Translation in the Classroom: A Study of Students' Attitudes and Strategies. Retrieved from http://du.diva-portal.org/smash/get/diva2:519125/FULLTEXT01.pdf. (2011).

${ }^{10}$ Jin, L., \& Deifell, E, Foreign Language Learners' Use and Perception of Online Dictionaries: A Survey Study.MERLOT Journal of Online Learning and Teaching, 9 (4), 515-533. (2013).

${ }^{11}$ Groves, M., \& Mundt, K, Friend or foe? Google Translate in language for academic purposes. English for Specific Purposes, 37, (2015) 112-121. (2015). 
lakukan akan dianalisis oleh peneliti didukung dengan tanggapan mereka melalui metode angket dan wawancara.

\section{Hasil dan Pembahasan}

\section{A. Peran Google Translate dalam Pembelajaran Tarjamah}

Berbagai masalah akan dihadapi oleh mahasiswa saat melakukan penerjemahan teks Arab. Mahasiswa akan dihadapkan dengan masalah yang membuat mereka kesulitan dalam menerjemahkan. Salah satu masalah yang sering dihadapi mahasiswa adalah masalah dari sisi internal dalam diri mereka sendiri, seperti minimnya penguasaan mufrodat dan juga kurangnya pemahaman tata bahasa. Penguasaan mufrodat yang minim juga dikeluhkan oleh salah satu mahasiswa PBA yang merasa bahwa ini merupakan salah satu kendala dalam menerjemahkan:

"Kesulitanya karena saya minim dalam penguasaan Mufrodat (kosa kata) jadi sangat sulit untuk menerjemahkan teks berbahasa Arab dengan baik. Padahal mufrodat merupakan dasar awal yang harus dikuasai untuk menerjemahkan."12

Untuk dapat menerjemahkan teks bahasa Arab secara sempurna harus dibangun oleh kosa kata yang tepat dan memadai, serta kaya akan bentuk dan maknanya. Itu akan memberikan wibawa tersendiri bagi penggunanya. Hal ini karena hasil sebuah terjemahan akan memberikan warna tersendiri apabila kosa kata yang digunakan mampu menyampaikan maksud yang diinginkan oleh penulis.

Penambahan kosa kata seorang mahasiswa secara umum merupakan bagian yang penting, baik dari proses pembelajaran tarjamah atau peningkatan kemampuan tarjamah. Makna yang dihasilkan oleh sebuah kosa kata dapat memunculkan ide tersendiri bagi seorang penerjemah. Oleh sebab itu, penguasaan mufrodat yang baik akan dapat menghasilkan terjemahan yang baik juga. Untuk dapat menambah kekurangan mufrodat yang dimiliki, mahasiswa dapat mencari pada kamus sebagai media untuk menambah kosa kata. Pencarian kosa kata juga bisa deperoleh lewat mesin penerjemah Google Translate yang sekarang sudah bisa diakses lewat Smart Phone.

Kosa kata juga harus ditunjang dengan pengetahuan tentang masalah ilmu tata bahasa (Qawa'id) sebab penerjemahan suatu kalimat akan di tentukan lewat kedudukan sebuah kata, dan sebuah kata yang sama akan mempunyai makna yang berbeda sesuai dengan konteks sebuah kalimat. Kesulitan dalam menerjemahkan teks Arab salah satu yang juga dikeluhkan oleh mahasiswa yaitu karena minimnya pengetahuan ilmu Qawa'id yang membuat mereka akhirnya kesulitan dalam menerjemahkan dan harus membutuhkan alat bantu untuk mengatsi masalah ini. Seperti yang di ungkapkan oleh salah satu mahasiswa PBA:

"Kemampuan dalam menerjemah saya masih minim sekali dan kesulitanya seperti menggabungkan kalimat agar sesuai. Contohnya seperti mana yang harus ditambah alif atau al atau sejenisnya. Intinya yang berkaitan dengan Qowa'idnya."'13

Qawa'id merupakan seperangkat aturan yang harus digunakan oleh mahasiswa dalam menerjemahkan teks berbahasa Arab dan Qawaid dalam sebuah bahasa merupakan suatu deskripsi tertulis dari aturan-aturan suatu bahasa tersebut. Qawa'id juga mempengaruhi susunan dan hubungan sebuah kata dalam sebuah kalimat. Antara Mufrodat dan Qawa'id tidak bisa dipisahkan karena ini bagian dari sebuah syarat untuk dapat menerjemahkan teks berbahasa Arab dengan baik. Selain itu, Qawa'id membuat hasil terjemahan sesuai dengan apa yang dimaksudkan oleh. Ini yang menjadi letak pentingya penguasaan mufrodat dan Qawa'id agar dapat menghasilkan penerjemahan yang baik.

\footnotetext{
${ }^{12}$ Wawancara dengan Bella Rosdiana, Mahasiswa PBA, pada 02 Maret 2019

${ }^{13}$ Wawancara dengan Lutfiyatul Munawaroh, Mahasiswa PBA, pada 03 Maret 2019
} 
Mahasiswa membutuhkan sebuah alat bantu yang digunakan saat menghadapi kesulitan dalam menerjemahkan. kamus merupakan salah satu alat bantu yang digunakan untuk mengatasi kesulitan itu. Seperti yang dikatakan oleh salah satu mahasiswa PBA:

\section{"Saat saya menghadapi kesulitan dalam menerjemahkan otomatis saya akan langsung membuka kamus untuk mencari arti dari kata yang belum saya ketahui." 14}

Kegiatan menerjemah tidak akan pernah lepas dari sebuah kendala atau masalah. Oleh karena itu, mahasiswa sudah mengantisipasi hal itu dengan membawa alat bantu yaitu kamus. Ini akan membuat mereka mudah mengatasi masalah yang dihadapi saat bertemu dengan lafadzlafadz yang tidak mereka ketahui untuk mencari maknanya. Akan tetapi sekarang sangat jarang mahasiswa yang membawa kamus ke kampus saat mereka mengikuti jam perkuliahan karena beban kamus yang dianggap cukup berat. Perkembangan teknologi membuat mahasiswa menggunakan alat bantu yang lain sebagai pengganti kamus dalam mencari makna sebuah lafadz yang belum mereka ketahui. Aplikasi Google Translate merupakan salah satu pengganti dari kamus tersebut. Mereka mengatakan bahwa ini menjadi salah satu alat bantu yang dipakai untuk mencari makna sebuah kata yang belum mereka ketahui. Tidak hanya itu, Google Translate juga dianggap mampu untuk menambah kosa kata saat penguasaan kosa kata yang mereka miliki masih minim. Seperti yang diungkapkan oleh salah satu mahasiswa PBA mengenai penggunaan Google Translate:

"Sifat saya sendiri yang terkadang malas membuka kamus, membuat saya membutuhkan saluran yg lebih instan seperti aplikasi Google Translate." 15

Kecenderungan mahasiswa untuk menggunakan Google Translate tidak seperti penggunaan kamus yang menjadi alat bantu utama. Akan tetapi, hampir seluruh mahasiswa pernah menggunakan aplikasi ini sebagai alat bantu dalam proses penerjemahan. Hal ini dibuktikan dengan riset yang dilakukan oleh peneliti terhadap mahasiswa UIN Walisongo Semarang. Hasil penelitian yang dilakukan kepada mahasiswa PBA menunjukan bahwa Google Translate ikut berperan aktif dalam proses penerjemahan. Di bawah ini akan dijelaskan aspek-aspek yang menjelaskan bahwa Google Translate sangat berperan dalam proses penerjemahan:

\section{Intensitas Penggunaan Google Translate.}

Hasil perhitungan angket terdapat 50\% yang mengatakan bahwa dalam menerjemahakan mereka selalu menggunakan Google Translate. Ini disebabkan oleh cara penggunaannya yang relatif mudah dan juga tidak memerlukan proses loading yang lama. Pada perhitungan angket menyebutkan terdapat 55\% mahasiswa memiliki aplikasi Google Translate yang selalu tersedia untuk digunakan dalam menerjemahkan teks berbahasa Arab. Keadaan ini menunjukan intensitas penggunaan Google Translate dikalangan mahasiswa cukup besar. Setiap proses penerjemahan pasti akan menghadapi berbagai permasalahan yang membuat mahasiswa membutuhkan sebuah alat bantu sebagai solusi dalam memecahakan masalah tersebut dan Google Translate ikut serta dalam mengatasi masalah yang dihadapi oleh mahasiswa dalam menerjemahkan. Untuk hasil total rata-rata dari perhitungan angket untuk aspek intensitas penggunaan Google Translate yaitu sebesar $58 \%$.

\section{Fungsi Google Translate}

Aplikasi ini juga memudahkan mereka dalam proses penerjemahan yang sebelumnya tanpa ada mesin penerjemah ini. Terdapat prosentase sebanyak $64 \%$ yang beranggapan bahwa menerjemahkan teks Bahasa Arab adalah perkara sulit yang membuat mereka akan mudah bosan

\footnotetext{
${ }^{14}$ Wawancara dengan Abdullah Haidar, Mahasiswa PBA, pada 03 Maret 2019

${ }^{15}$ Wawancara dengan Nur Lailatul Maulidiyah, Mahasiswa PBA, pada 02 Maret 2019
} 
ketika haruss berhadapan dengan teks Bahasa Arab secara terus menerus tanpa mendapatkan hasi yang diharapkan. Kesimpulan yang bisa diambil yaitu dengan fungsi aplikasi ini maka Google Translate dianggap bereperan dalam proses penerjemahan yang dilakukan oleh mahasiswa PBA. Hasil total dari perhitungan angket untuk aspek fungsi Google Translate yaitu sebesar $60 \%$.

\section{Keefektifan Google Translate}

Banyak juga mahasiswa yang mengatakan bahwa aplikasi mesin penerjemah ini menghasilkan penerejemahan yang relatif mirip dengan apa yang ada pada kamus. Pada riset yang dilakukan peneliti terdapat $41 \%$ yang mengatakan hal demikian. Akan tetapi biasanya saat menerjemahkan teks yang pendek seperti Mufrodat dan idiom tidak seluruhnya hasil penerjemahan Google Translate sempurna, dengan kata lain aplikasi ini hanya cukup membantu saat digunakan dalam membantu kata yang dapat di deteksi oleh mesin saja. Oleh karena itu, peningkatan kualitas dari Google Translate harus selalu di-update agar menghasilkan penerjemahan yang cukup baik. Hasil total dari perhitungan angket untuk aspek Keefektifan Google Translate yaitu sebesar $45 \%$.

\section{Cara penggunaan Google Translate}

Beragam cara dilakukan mahasiswa dalam peggunaan aplikasi ini sebagai alat bantu mereka dalam menerjemahkan. Hal yang terpenting adalah seberapa besar peranan yang ditimbulkan oleh penggunaan aplikasi Google Translate sehingga membuat mereka mampu menghadapi kesulitan dalam menerjemahkan. Jika penggunaan aplikasi ini untuk sekedar membantu itu tidak menjadi masalah, inti pokoknya jangan samapai membuat mahasiswa ketergantungan dalam penggunaanya. Hasil total dari perhitungan angket untuk aspek cara penggunaan Google Translate sebesar 59\%.

\section{Keefisienan Google Translate}

Penggunaan Smart Phone di kalangan mahasiswa bukan hal yang baru lagi di mata kita. Oleh sebab itu, penggunaan mesin penerjemah ini sering dipakai oleh mahasiswa karena hanya cukup mendownload saja lewat aplikasi Play Store dengan Smart Phone yang mereka bawa. Mereka tidak harus menggunakan komputer atau laptop untuk mengakses aplikasi ini. Hasil riset juga mengatakan bahwa mahasiswa banyak yang setuju tentang keefisienan penggunaan aplikasi ini. Hasil total dari perhitungan angket untuk aspek keefisienan Google Translate yaitu sebesar $61 \%$.

\section{Kualitas Google Translate}

Kemungkinan yang didapatkan dari penerjemahan Google Translate terkadang tidak sesuai dengan yang diinginkan. Tapi hasilnya masih bisa diharapkan saat kondisi mendesak. Ini berarti kualitas Google Translate tidak terlalu buruk pada waktu kita gunakan dalam menerjemahkan teks yang dirasa sulit. Hasil total dari perhitungan angket untuk aspek kualitas Google Translate yaitu ada $63 \%$.

\section{Fasilitas Google Translate}

Berbagai fasilitas tertanam dalam aplikasi Google Translate sebagai fitur yang bisa diandalkan dalam mempermudah penerjemahan. Pada Google Translate pendeteksi kata merupakan salah satu fasilitas yang sering dipakai oleh mahasiswa PBA, karena dengan adanya pendeteksi kata ini, kalimat yang kurang tepat pada beberapa kata akan secara otomatis muncul pada bawah layar teks yang ingin diterjemahkan. Hal ini mengurangi kesalahan dalam penerjemahan apabila teks yang ingin diterjemahkan terdapat huruf yang salah atau kurang. Tidak hanya itu, secara otomatis hasil dari penerjemahan akan lebih sempurna dikarenakan sebelum penerjemahan di proses, maka akan dilakukan terlebih dahulu perbaikan kata melalui fasilitas 
pendeteksi kata. Hasil perhitungan angket juga mengatakan bahwa $62 \%$ fasilitas pendeteksi kata ini mambantu proses penerjemahan teks berbahasa Arab.

Fasilitas ini yang selalu akan di manfaatkan oleh mahasiswa agar mendapatkan hasil penerjemahan yang baik, karena hasil penerjemahan tidak akan terdeteksi jika penulisan teks yang akan kita terjemahkan terdapat kekeliruan. Mahasiswa menganggap berbagai fasilitas di atas dapat membuat mereka lebih mudah menerjemahkan teks Bahasa Arab yang terkadang ada beberapa kesulitan yang sering mereka hadapi dalam menerjemahkan teks Bahasa Arab. Hasil total dari perhitungan angket untuk aspek fasilitas Google Translate yaitu ada 47\%.

\section{Manfaat Google Translate}

Pada mahasiwa PBA, Google Translate dianggap ikut berperan aktif dan memberikan manfaat yang cukup besar dalam proses penerjemahan. Beberapa mahasiswa beranggapan bahwa Google Translate masih mereka pergunakan sebagai sarana yang dibutuhkan dalam menerjemhakan. Tidak lain karena manfaat yang didapatkan, tetapi mereka sadar bahwa Google Translate bukan satu-satunya sarana pembantu mereka, sebab Google Translate hanya salah satu dari berbagi sarana yang mereka gunakan dalam menambah penguasaan Mufrodat yang masih minim. Hasil total dari perhitungan angket untuk aspek manfaat Google Translate yaitu sebesar $58 \%$.

\section{Kekurangan Google Translate}

Mahasiswa PBA semester IV UIN Walisongo Semarang sebenarnya sudah memahami dan menyadari akan kekurangan yang dimiliki aplikasi Google Translate ini dan sudah seharusnya penggunaan yang berlebihan tidak dilakukan untuk mencegah kesalahan yang lebih masif. Hasil total dari perhitungan angket untuk aspek kekurangan Google Translate yaitu ada $52 \%$.

\section{Kelebihan Google Translate}

Pada saat menerjemahkan teks berbahasa Arab, faktor hafalan mufrodat yang mumpuni akan memudahkan mahasiswa lebih mudah dalam proses penerjemahan teks. Namun, dari hasil penelitian yang dilakukan oleh peneliti, masih terdapat banyak kendala dalam proses penerjemahan teks berbahasa Arab disebabkan penguasaan mufrodat yang minim pada mahasiswa. Adanya kesulitan tersebut, membuat penggunaan aplikasi Google Translate sangat membantu mahasiswa dalam menerjemahkan teks-teks berbahasa Arab. Dari hasil penelitian yang dilakukan oleh peneliti mengenai hal tersebut 65\% menganggap Google Translate membantu dalam proses menerjemahkan jika mereka memiliki hafalan mufrodat yang terbatas. Hasil total rata-rata dari perhitungan angket untuk aspek kelebihan Google Translate yaitu sebesar 56\%.

\section{B. Dampak Penggunaan Google Translate dalam Penerjemahan Teks Arab}

Penggunaan Google Translate di era teknologi ini semakin sering digunakan sebagai jalan alternatif menerjemahkan. Hal ini dikarenakan oleh beberapa sebab. Seperti penguasaan mufrodat dan juga lemahnya pengetahuan tentang ilmu tata bahasa (Qawa'id). Ini menjadi sebuah bahan pertimbangan yang menjadikan mahasiswa dalam mencari kemudahan lewat kecanggihan teknologi yang berkembang saat ini. Kita tidak bisa mencegah hal tersebut, karena hampir seluruh mahasiswa sekarang mempunyai Smart Phone yang mereka gunakan untuk mengakses internet, sebagai cara untuk masuk dalam berbagai aplikasi yang di butuhkan untuk membantu mempermudah proses pembelajaran. Salah satu yang digunakan mereka dalam mengatasi kesulitan mata kuliah tarjamah yaitu aplikasi Google Translate. Akan tetapi, sebenrnya penggunaan aplikasi ini sudah mereka ketahui dampaknya baik dari sisi positifnya maupun dari sisi negatifnya.

Dampak positif yang ditimbulkan dari penggunaan Google Translate yaitu: 
1. Mempermudah mahasiswa dalam menerjemahkan saat menghadapi kendala dalam menerjemahkan

2. Menambah pengetahuan tentang aplikasi penerjemahan sebagai alat bantu kedua setelah kamus

3. Menambah kosa kata baru saat mereka ingin menambah penguasaan kosa kata yang masih kurang

4. Menambah motivasi dalam menerjemah karena berbagai fasilitas yang terdapat dalam aplikasi Google Translate

5. Mengurangi kesulitan kaidah tata Bahasa Arab saat pengetahuan tentang kaidah Bahasa Arab masih minim.

6. Mempermudah mahasiswa yang minim dalam penguasaan ilmu sharaf. Karena jika menggunakan kamus mereka harus mengetahui asal sebuah kata.

Hal-hal di atas merupakan dampak positif yang ditimbulkan dari penggunaan Google Translate dan sekaligus juga sebagai keuntungan untuk mahasiswa saat menggunakan aplikasi Google Translate karena hasil yang di dapatkan juga tidak terlalu buruk. Seperti yang dikatakan oleh Bapak Rosidi :

"Google Translate menurut saya aplikasi untuk menambah pengetahuan. Tapi, jangan dijadikan satu-satunya alat untuk menerjemahkan yang baik, kalau mencari mufrodat iya, tapi kalau sistem menerjemah tidak bisa, karena tidak punya bahasa yg baik. Jadi, hanya membantu mahasiswa untuk mempermudah saja, terutama dari segi mufrodat. Disamping itu, harus cek di kamus juga, soalnya kalau mengambil dari Google semua nanti salah kaprah. Perannya sangat membantu beberapa persen. Google Translate berbasis internet, sekarang pakai Smart Phone juga bisa. Kemudian, disana terkadang ada pilihan. Kira-kira yg munasibah bisa di ambil. Intinya membantu, jadi dipersilahkan tapi jangan sampai kamus lepas. Karena, kamus membantu untuk menambah pengetahuan sharaf-nya." 16

Walaupun aplikasi ini cukup membantu, akan tetapi jangan sampai dijadikan satu-satunya sebuah media yang digunakan untuk membantu proses penerjemahan. Penggunaan yang wajar masih diperbolehkan oleh beberapa dosen. Aplikasi ini merupakan aplikasi instan yang dikeluarkan oleh Google sebagai alat bantu dalam menerjemahkan dan otomatis memiliki dampak negatif dalam penggunaanya. Terdapat beberapa dampak negatif yang ditimbulkan apabila menggunakan aplikasi ini secara berlebihan, yaitu:

a. Menjadikan mahasiswa ketergantungan

b. Membuat mahasiswa malas mahasiswa karena sudah tidak perlu lagi untuk belajar teori dan kaidah terjemah

c. Usaha dalam menerjemahkan secara manual berkurang

d. Tidak percaya dengan hasil terjemahan mereka sendiri

${ }^{16}$ Wawancara dengan Rosidi, M.SI, Dosen Tarjamah UIN Walisongo Semarang, pada 05 Maret 2019 
Berbagai dampak yang timbul dalam penggunaan aplikasi ini harus bisa diantisipasi oleh dosen dan mahasiswa sendiri, sehingga tidak menjadi sebuah kebiasaan yang berdampak buruk kedepannya. Seperti yang dikatakan oleh Ibu Fina Sa'adah:

"Sekarang banyak Smart Phone, jadi mereka bisa menggunakan dengan mudah. Akan tetapi saya melarang pengunaan itu, karena kalau mereka sudah diperbolehkan menggunakan mereka tidak akan bisa dibatasi. Hal ini juga tidak mendidik dan usaha mereka akan berkurang, tapi kalau susah kemudian buka kamus itu ada tantangan buat mereka dan ada semangat juga. Jadi nantinya sharafnya juga ikut main." ${ }^{\prime 7}$

Harus diketahui bahwa Google Translate hanya sebagai alat bantu saja dan bukan menjadi acuan utama saat menemukan kesulitan dalam menerjemahkan. sehingga nantinya mahasiswa tidak ketergantungan dalam pemakaiannya. Para dosen selalu khawatir apabila penggunaan Google Translate membuat mereka malas dalam menerjemahkan, khususnya menerjemahkan secara manual. Mereka mengharapkan kamus menjadi alat bantu utama dalam mengatasi kesulitan menerjemahkan sebab hasilnya akan lebih baik dibanding dengan menggunakan mesin penerjemahan Google Translate.

\section{Penutup}

Dari hasil penelitian yang telah dilakukan selama menyelesaikan kajian ini, peneliti berkeyakinan bahwa kajian ini mempunyai signifikansi bagi pengembangan pendidikan Bahasa Arab yang ada di Indonesia dengan mengacu pada penelitian evaluatif tentang Google Translate sebagai alat bantu dalam proses penerjemahan. Untuk mengakhiri penulisan kajian ini, penulis mempunyai saran sebagai berikut: 1) Untuk mahasiswa: Google Translate hanya merupakan sebuah alat bantu yang digunakan untuk membantu proses penerjemahan. Aplikasi ini tidak harus menjadi tumpuan utama yang digunakan sebagai alat bantu penerjemahan karena masih banyak kekurangan yang terdapat pada hasil penerjemahan. Masih ada kamus yang menjadi tumpuan dalam membantu proses penerjemahan ketika mengalami kesulitan dalam menerjemahkan. Membiasakan untuk berlatih adalah salah satu cara yang paling tepat untuk meningkatkan kualitas kemampuan dalam menerjemahkan teks berbahasa Arab. Karena, dengan membiasakan berlatih maka kemampuan kita dalam menerjemahkan akan selalu meningkat dan hasil penerjemahan yang kita lakukan akan semakin menjadi lebih baik. 2) Untuk Dosen: Seorang dosen adalah tauladan bagi mahasiswanya, maka sudah sepantasnya seorang dosen memiliki keterampilan dalam bidang pedagogik maupun profesional. Hal tersebut akan mengurangi kesalahan-kesalahan dalam pembelajaran, yang berdampak fatal bagi mahasiswa. Khususnya dalam pembelajaran tarjamah. Seorang dosen dapat menekankan pada mahasiswa agar lebih banyak berlatih menerjemahkan. 3) Bagi peneliti selanjutnya: Penelitian tentang Google Translate dalam kajian ini diharapkan dapat menjadi inspirasi bagi para ilmuwan pendidikan Bahasa Arab di Indonesia. Penelitian evaluatif terkait pendidikan bahasa Arab dinilai masih sangat minim. Oleh karena itu, diharapkan peneliti selanjutnya mampu memberikan nuansa baru bagi penelitian bahasa Arab di Indonesia

${ }^{17}$ Wawancara dengan Fina Sa'adah, M. Ag, Dosen Tarjamah UIN Walisongo Semarang, pada 03 Maret 


\section{Bibliografi}

B, Turovsky,. Ten Years of Google Translate. Google Translate. Retrieved from https://www.blog.google/products/translate/ten-years-of-google-translate/. (2016).

C, Ducar. \& Schocket, D. H. Machine Translation and the L2 Classroom: Pedagogical Solutions for Making Peace with Google Translate. Foreign Language Annals, 51(4), 779-795. https://doi.org/10.1111/flan.12366. (2018).

E, Alhaisoni,. \& Alhaysony, M. An Investigation of Saudi EFL University Students' Attitudes towards the Use of Google Translate. International Journal of English Language Education, 5 (1), 72-82. https://doi.org/10.5296/ijele.v5i1.10696. (2017).

E, Josefsson,. Contemporary Approaches to Translation in the Classroom: A Study of Students' Attitudes and Strategies. Retrieved from http://du.divaportal.org/smash/get/diva2:519125/FULLTEXT01.pdf. (2011).

I, Garcia, \& Pena, M.I. Machine translation-assisted language learning: writing for beginners. Computer Assisted Language Learning, 24 (5),471487. Retrieved from http://dx.doi.org/10.1080/09588221.201. (2011).

L, Jin. \& Deifell, E. Foreign Language Learners' Use and Perception of Online Dictionaries: A Survey Study. MERLOT Journal of Online Learning and Teaching, 9(4), 515-533. (2013).

M, Dewaele, J. Why the Dichotomy 'L1 Versus LX User' is Better than 'Native Versus Nonnative Speaker'. Applied Linguistics, 39 (2), 236-240. https://doi.org/10.1093/applin/amw055. (2018).

M, Groves. \& Mundt, K. Friend or foe? Google Translate in language for academic purposes. English for Specific Purposes, 37, (2015).

P, Koehn,. Statistical Machine Translation. Cambridge: Cambridge University Press. (2009).

R. Amin, E. A. A Review of Research into Google Apps in the Process of English Language Learning and Teaching. Arab World English Journal,11 (1), 399-418. https://doi.org/10.24093/awej/vol11no1.27. (2020).

Wawancara dengan Rosidi, M.SI, Dosen Tarjamah UIN Walisongo Semarang, pada 05 Maret 2019

Wawancara dengan Fina Sa'adah, M. Ag, Dosen Tarjamah UIN Walisongo Semarang, pada 03 Maret 2019 